\title{
1 Lipidomic signature of the green macroalgae Ulva rigida farmed in a sustainable 2 integrated multi-trophic aquaculture
}

3 Diana Lopes ${ }^{1,2,3}$, Ana S. P. Moreira ${ }^{1,2}$, Felisa Rey ${ }^{1,32}$, Elisabete da Costa ${ }^{1,2,3}$, Tânia Melo ${ }^{1}$, Elisabete

4 Maciel $^{1,2,3}$, Andreia Rego ${ }^{4}$, Maria H. Abreu ${ }^{4}$, Pedro Domingues ${ }^{1}$, Ricardo Calado ${ }^{3}$, Ana I. Lilleb $\emptyset^{3}$, M.

5 Rosário Domingues ${ }^{1,2, *}$

6

71 Centro de Espectrometria de Massa, Departamento de Química \& QOPNA, Universidade de Aveiro,

8 Campus Universitário de Santiago, 3810-193 Aveiro, Portugal. dianasalzedaslopes@ua.pt (DL)

$9 \quad$ orcid.org/0000-0002-0072-0492; ana.moreira@ua.pt (AM); felisa.rey@ua.pt (FR); elisabetecosta@ua.pt

10 (EC); taniamelo@ua.pt (TM); elisabete.maciel@ua.pt (EM); p.domingues@ua.pt (PD); mrd@ua.pt (MRD)

11

2 Departamento de Quimica \& CESAM \& ECOMARE, Universidade de Aveiro, Campus Universitário de Santiago, 3810-193 Aveiro, Portugal. E-mail:

3Departamento de Biologia \& CESAM \& ECOMARE, Universidade de Aveiro, Campus Universitário de Santiago, 3810-193 Aveiro, Portugal. E-mail: rjcalado@ua.pt (RC); lillebo@ua.pt (AIL)

4 ALGAplus - Produção e comercialização de algas e seus derivados, Lda., 3830-196 Ílhavo, Portugal. Email: amrego@algaplus.pt

$(\mathrm{AR})$; htabreu@algaplus.pt

(MHA)

\footnotetext{
* Author to whom correspondence should be addressed: mrd@ua.pt; +351 234401505.
} 


\section{Abstract}

32 Ulva species, green macroalgae, are widely distributed in the water across the globe,

33

34 being one of the most heavily-traded edible seaweeds. Nonetheless, although this genus has been largely used in scientific studies, its lipidome remains rather unexplored. The present study sheds light over the lipid profile of Ulva rigida produced in a land-based integrated multi-trophic aquaculture (IMTA) system using liquid chromatography coupled to high resolution mass spectrometry for molecular lipid species identification. The lipidome of $U$. rigida revealed the presence of distinct beneficial $n-3$ fatty acids for human health, namely alpha-linoleic acid (ALA) and docosapentaenoic acid (DPA). A total of 87 molecular species of glycolipids, 58 molecular species of betaine lipids and 57 molecular species of phospholipids were identified in the lipidome of $U$. rigida including some species bearing PUFA and with described bioactive properties. Overall, the present study contributes to the valorization and quality validation of sustainably farmed $U$. rigida.

Keywords: Chlorophyta, Edible, Lipidome, Mass spectrometry, Seaweed, Ulva rigida 
Edible macroalgae are a good source of beneficial compounds for human health that display distinct functional properties that stimulate interest to number of high-value chains (e.g., medical, nutraceutical and cosmeceutical) (Holdt and Kraan 2011; Leal et al. 2013; Abreu et al. 2014; Rajauria 2015; Roohinejad et al. 2016). Ulva spp. have long been listed in FAO as one of the main macroalgae for commercial use (Naylor 1976). These popular green seaweeds can be used fresh, dried, or in liquid extracts, either for direct or processed consumption worldwide (McHugh 2003; Barriga et al. 2017). Popularly known in the human food market as sea lettuce, Ulva spp. belongs to class Ulvophyceae and can be found in marine and brackish waters, being widely distributed across the globe. Ulva species are well adapted to aquaculture production and can be successfully cultured by using an integrated multi-trophic aquaculture (IMTA) framework (Bolton et al. 2008; Msuya and Neori 2008; Marinho et al. 2013; Shpigel et al. 2017). This innovative and sustainable culture approach mimics the natural ecosystem of species from different trophic levels, associating the production of fed species (e.g. finfish) with other extractive organisms, namely marine invertebrates and/or algae, that incorporate organic and inorganic compounds resulting from the metabolism of fed species, as well as from uneaten feed. Overall, IMTA promotes a balanced production framework that is environmentally sustainable and viable from an economic point of view (Barrington et al. 2009; Chopin et al. 2012). The culture of seaweeds under an IMTA approach allows the removal of excess nutrients, namely phosphorus and nitrogen, from wastewater (Neori 2009; Lawton et al. 2013), while enhancing quality and stability of seaweeds biomass and their biochemical profile (Abreu et al. 2014). Ulva species are consumed directly as "sea vegetables" and used as a food and feed ingredient. They are also recognized as an important source of valuable polysaccharides 
(such as ulvans) and oligosaccharides rich in functional groups that bind important microelements for human and animal nutrition (Lahaye and Robic 2007; Stengel et al. 2011; Berri et al. 2016; Wijesekara et al. 2017). However, to date, the lipid profile of Ulva spp. is still poorly studied at molecular level and few articles have reported their lipid characterization (Takahashi et al. 2002; Rozentsvet and Nesterov 2012; Ragonese et al. 2014), with most studies solely describing their fatty acid (FA) profile (van Ginneken et al. 2011; Ragonese et al. 2014; Kendel et al. 2015). While lipids may solely represent from 1 to $3 \%$ of the whole algal dry matter, they do display an important nutritional value, with emphasis into polyunsaturated fatty acids (PUFAs) from the $n-3$ (e.g., alphalinolenic acid, eicosapentaenoic acid and docosahexaenoic acid) and n-6 (linoleic acid, gamma-linolenic acid and arachidonic acid) (Kumari et al. 2010). As essential PUFAs are not synthesized by humans, they need to be obtained through diet to provide energy and others health benefits (e.g., reduce the risk of coronary disease and blood cholesterol) (Ginzberg et al. 2000; Simopoulos 2008; Kendel et al. 2015). Furthermore, PUFAs are also precursors of important mediators that play a key-role in inflammation and regulation of immunity (Calder 2001). These biomolecules mostly occur in their esterified form in polar lipids, namely phospholipids (PLs) and glycolipids. This feature enhances the nutritional properties of these classes of polar lipids. Additionally, glycolipids isolated from macroalgae have already been described as displaying bioactive proprieties, namely antitumoral (Ohta et al. 1998; Eitsuka et al. 2004), anti-inflammatory (Banskota et al. 2013, 2014), antimicrobial (El Baz et al. 2013; Parveez et al. 2017) and antiviral activity (Wang et al. 2007).

The potential added value of macroalgal polar lipids has received a new momentum with the advent of mass spectrometry-based approaches, which have already been employed to provide an in-depth characterization of lipidomic signatures of different macroalgae, 
namely Chondrus crispus (Melo et al. 2015), Codium tomentosum, Gracilaria sp., and Porphyra dioica (da Costa et al. 2015, 2017, 2018). The aim of the present study is analyzed the lipidome of Ulva rigida (C.Agardh, 1823) from a land-based IMTA system using liquid chromatography high resolution mass spectrometry - based approach. The data presented will contribute to promote on-going efforts in the responsible, controlled and sustainable production of high-value macroalgae.

\section{Material and methods}

\section{Reagents}

HPLC grade chloroform $\left(\mathrm{CHCl}_{3}\right)$ and methanol $\left(\mathrm{CH}_{3} \mathrm{OH}\right)$ were purchased from Fisher Scientific Ltd. (Loughborough, UK). All other reagents were purchased from major commercial sources. Milli-Q water was obtained from a water purification system (Synergy, Millipore Corporation, Billerica, MA, USA). Phospholipid internal standards 1,2-dimyristoyl-sn-glycero-3-phosphocholine (dMPC), 1,2-dimyristoyl-sn-glycero-3phosphoethanolamine (dMPE), 1,2-dimyristoyl-sn-glycero-3-phospho-(10-rac-glycerol) (dMPG), 1,2-dimyristoyl-sn-glycero-3-phospho-L-serine (dMPS), 1,2-dipalmitoyl-snglycero-3-phosphatidylinositol (dPPI), N-palmitoyl-D-erythrosphingosylphosphorylcholine (NPSM), 1-nonadecanoyl-2-hydroxy-sn-glycero-3phosphocholine (LPC) were purchased from Avanti Polar Lipids, Inc. (Alabaster, AL).

\section{Biomass}

The fresh biomass of Ulva rigida (C.Agardh, 1823) was produced by ALGAplus (production site located at Ria de Aveiro coastal lagoon, mainland Portugal, 40³6'43"N, $8^{\circ} 40^{\prime} 43^{\prime \prime} \mathrm{W}$ ) in an IMTA system, harvested in November 2016 (batch U1.4616.L). The 
127 ALGAplus IMTA system is composed of a fish organic certified production units 128 (seabass and seabream) and the seaweed land-based tank system. The water flows from 129 the fish units, to the seaweed tanks and then to the exit channel that discharges clean water 130 into the coastal lagoon. Seaweeds are cultivated using exclusively water input from the 131 fish farm (nothing is added to the water). Stocking densities and water flows are manipulated in each season to achive optimal biomass yields and/or specific biomass quality traits (i.e. chemical composition, colour). After being harvest, all biological samples were cleaned to remove epiphytic foreign matters, washed with seawater that is sequentially filtered up to 25 micron and then sterilized by UV and Ozone treatment. The samples were then frozen at $-80{ }^{\circ} \mathrm{C}$, lyophilized, and stored at $-80{ }^{\circ} \mathrm{C}$ until lipid extraction.

Moisture and ash determination

Moisture was determined by drying freeze-dried samples ( $250 \mathrm{mg}$ x 5 replicates) in crucibles on an oven at $105^{\circ} \mathrm{C}$ for $15 \mathrm{~h}$. For ash determination, the dried biomass in the crucibles was first pre-incinerated for 20 min using a heating plate and then placed in a muffle furnace at $575^{\circ} \mathrm{C}$ for $6 \mathrm{~h}$.

\section{Nitrogen determination and protein estimation}

Nitrogen content of freeze-dried samples ( $2 \mathrm{mg}$ x 5 replicates) was obtained by elemental analysis on a Leco Truspec-Micro CHNS 630-200-200 elemental analyser at combustion furnace temperature $1075^{\circ} \mathrm{C}$ and afterburner temperature $850^{\circ} \mathrm{C}$. Nitrogen was detected using thermal conductivity. The protein content was estimated from the nitrogen 2016). 
Lyophilized samples were homogenized in a mortar and pestle until to obtain small-sized incubation in ice on rocking platform shaker (Stuart equipment, Bibby Scientific, Stone, UK) for $2.5 \mathrm{~h}$, the mixture was centrifuged (Selecta JP Mixtasel, Abrera, Barcelona, Spain) for $10 \mathrm{~min}$ at $2000 \mathrm{rpm}$ and the organic phase was collected in a new glass tube. The biomass residue was re-extracted twice with $2 \mathrm{~mL}$ of $\mathrm{MeOH}$ and $1 \mathrm{~mL}$ of $\mathrm{CHCl}_{3}$. To wash the lipid extract and induce phase separation, $2.3 \mathrm{~mL}$ of Milli-Q water was added to the final organic phase, following by centrifugation for $10 \mathrm{~min}$ at $2000 \mathrm{rpm}$. The organic lower phase was collected in a new glass tube, dried under nitrogen stream. Lipid extracts were then transferred to amber vials, dried again, weighed, and stored at $-20{ }^{\circ} \mathrm{C}$. Lipid content was estimated as dry weight percentage.

Fatty Acid analysis by Gas Chromatography-Mass Spectrometry (GC-MS)

167 Fatty acid methyl esters (FAMEs) were prepared using a methanolic solution of potassium hydroxide (2.0 M) (Melo et al. 2015). A volume of $2 \mu \mathrm{L}$ of hexane solution containing FAMEs was analyzed by gas chromatography-mass spectrometry (GC-MS) on a GC system (Agilent Technologies 6890 N Network, Santa Clara, CA, USA) equipped with a DB-FFAP column with the following specifications: 30 m of length, 0.32 $\mathrm{mm}$ of internal diameter, and $0.25 \mu \mathrm{m}$ of film thickness (J \& W Scientific, Folsom, CA, 173 USA). The GC equipment was connected to an Agilent 5973 Network Mass Selective Detector operating with an electron impact mode at $70 \mathrm{eV}$ and scanning the range $\mathrm{m} / \mathrm{z}$ 50-550 in a $1 \mathrm{~s}$ cycle in a full scan mode acquisition. The oven temperature was 
at $25{ }^{\circ} \mathrm{C} \mathrm{min}^{-1}$, followed by linear increase at $2{ }^{\circ} \mathrm{C} \min ^{-1}$ to $210{ }^{\circ} \mathrm{C}$, then at $30{ }^{\circ} \mathrm{C} \min ^{-1}$ to $250{ }^{\circ} \mathrm{C}$, standing at $250{ }^{\circ} \mathrm{C}$ for $10 \mathrm{~min}$. The injector and detector temperatures were 220 and $280{ }^{\circ} \mathrm{C}$, respectively. Helium was used as the carrier gas at a flow rate of $1.4 \mathrm{~mL}$ $\min ^{-1}$. FA identification was performed considering the retention times and MS spectra of FA standards (Supelco 37 Component Fame Mix, Sigma-Aldrich), and by MS spectrum comparison with chemical databases (Wiley 275 library and AOCS lipid library). The relative amounts of FAs were calculated by the percent area method with proper normalization, considering the sum of all areas of identified FAs.

\section{Lipid extract fractionation}

187 Isolation of polar lipids from pigments was performed using a modification of Pacetti's method (da Costa et al. 2017). A sample of lipid extract (5 mg) was dissolved in $600 \mu \mathrm{L}$ of chloroform and transferred to a glass column with $500 \mathrm{mg}$ of silica gel (40-60 $\mu \mathrm{m}, 60$

\section{Hydrophilic interaction liquid chromatography mass spectrometry (HILIC-ESI-MS)}

Lipid extracts and fraction were analyzed by hydrophilic interaction liquid chromatography HILIC (Ascentis ${ }^{\circledR}$ Si column, $15 \mathrm{~cm} \times 1 \mathrm{~mm}, 3 \mu \mathrm{m}$, Sigma-Aldrich) on a High-Performance LC (HPLC) system (Thermo scientific AccelaTM) with a autosampler coupled online to a QExactive $^{\circledR}$ mass spectrometer with Orbitrap ${ }^{\circledR}$ technology. Mobile phase A consisted of $25 \%$ water, $50 \%$ acetonitrile and $25 \%$ methanol, with $1 \mathrm{mM}$ ammonium acetate in relation to 
the water volume, and mobile phase B consisted of $60 \%$ acetonitrile and $40 \%$ methanol, with the same amount of ammonium acetate in mobile phase A. The solvent gradient, flow rate through column and conditions used for acquisition of full scan LC-MS spectra and LC-MS/MS spectra in both positive and negative ion modes were the same as previously described (da Costa et al. 2015; Melo et al. 2015). Initially, 0\% of mobile phase A was held isocratically for $8 \mathrm{~min}$, followed by a linear increase to $60 \%$ of mobile phase A within $7 \mathrm{~min}$ and a maintenance period of $15 \mathrm{~min}$, returning to the initial conditions in $10 \mathrm{~min}$. A volume of $5 \mu \mathrm{L}$ of each sample, containing $10 \mu \mathrm{g}(10 \mu \mathrm{L})$ of lipid extract in $\mathrm{CHCl}_{3}, 4 \mu \mathrm{L}$ of phospholipid standards mix (dMPC - $0.02 \mu \mathrm{g}$, dMPE - $0.02 \mu \mathrm{g}$, NPSM - $0.02 \mu \mathrm{g}, \mathrm{LPC}-0.02 \mu \mathrm{g}, \mathrm{dPPI}-0.08 \mu \mathrm{g}, \mathrm{dMPG}-0.012 \mu \mathrm{g}, \mathrm{dMPS}-0.04 \mu \mathrm{g}$ ) and $86 \mu \mathrm{L}$ of eluent B, was introduced into the Ascentis Si column HPLC Pore column (15 $\mathrm{cm} \times 1 \mathrm{~mm}, 3 \mu \mathrm{m}$, Sigma-Aldrich) with a flow rate of $40 \mu \mathrm{L} \mathrm{min}{ }^{-1}$ at $30{ }^{\circ} \mathrm{C}$. The mass spectrometer with Orbitrap ${ }^{\circledR}$ technology was operated in simultaneous positive (electrospray voltage $3.0 \mathrm{kV}$ ) and negative (electrospray voltage $-2.7 \mathrm{kV}$ ) modes with high resolution with 70,000 and AGC target of $1 \times 10^{6}$, the capillary temperature was 250 ${ }^{\circ} \mathrm{C}$, and the sheath gas flow was $15 \mathrm{U}$. In MS/MS experiments, a resolution of 17,500 and AGC target of $1 \times 10^{5}$ was used and the cycles consisted in one full scan mass spectrum and ten data-dependent MS/MS scans were repeated continuously throughout the experiments with the dynamic exclusion of $60 \mathrm{~s}$ and intensity threshold of $1 \times 10^{4}$. Normalized collision energy ${ }^{\mathrm{TM}}(\mathrm{CE})$ ranged between 25,30 and $35 \mathrm{eV}$. Data acquisition was performed using the Xcalibur data system (V3.3, Thermo Fisher Scientific, USA). The identification of molecular species of polar lipids was based on the assignment of the molecular ions observed in LC-MS spectra, typical retention time, mass accuracy, and group and the fatty acyl chains for most of the molecular species. 
229

The total lipid content of the $U$. rigida was estimated by gravimetry of the lipid extracts. Also, samples were analyzed for the contents of moisture and ash, proteins, and carbohydrates and other compounds (estimated by difference). The mean moisture content (expressed as percentage of freeze-dried sample weight) of $U$. rigida was $6.41 \pm$ 0.84, which was considered to express the content of ash and other components as percentage of dry weight (DW). The content (\% DW) of ash and lipids was $26.47 \pm 0.51$ and $2.53 \pm 0.22$, respectively. Although the factor 6.25 is the most commonly used indirect nitrogen-to-protein conversion factor, studies have been shown that the protein content of seaweed is over-estimated by applying factor 6.25 (Hardouin et al. 2016). Angell et al. (2016) proposed the use of an universal nitrogen-to-protein conversion factor of 5 for determination of the protein content of seaweeds. Thus, both factors were used. Using factor 6.25 for protein estimation, the protein content (\%DW) was $17.75 \pm 0.492$, and the content of carbohydrates and other compounds (\% DW) was 53.25. Considering factor 5, the protein content decreased to $14.20 \pm 0.393$, while the content of carbohydrates and other compounds increased to 56.80 .

The fatty acids (FAs) profile of $U$. rigida revealed the presence of saturated FAs (SFAs) such as 14:0, 16:0, 18:0 and 22:0, monounsaturated FAs (MUFAs) such as 16:1 and 18:1 and PUFAs such as 16:4, 18:3, 18:4, 20:4, 20:5 and 22:5, as detailed in Table 1. The FA profile showed 16:0 and 18:0 as the most abundant with relative abundance of $43.41 \%$ and $19.30 \%$, respectively. It is also noteworthy the abundance of the PUFAs 16:4 (n-3) (3.76\%), 18:3 (n-3) (4.45\%), 18:4 (n-3) (8.82\%) and 22:5 (n-3) (3.76\%).

Polar lipid profile evaluated by HILIC-LC-MS and HILIC-LC-MS/MS allowed the identification at molecular level of glycolipids, betaine lipids and phospholipids in $U$. rigida. This lipidomic approach allowed the identification, in the case of glycolipids, the 
acidic glycolipid sulfoquinovosyl diacylglycerol (SQDG) and it lyso form sulfoquinovosyl monoacylglycerol (SQMG), as well as the neutral glycolipid digalactosyldiacylglycerol (DGDG) and monogalactosyldiacylglycerol (MGDG). SQDGs and SQMGs were identified as negative $[\mathrm{M}-\mathrm{H}]^{-}$ions in the LC-MS spectra. Overall, 20 molecular species of SQDG and 5 molecular species of SQMG (Table 2 and Fig. 1) were identified. The most abundant SQDG was assigned as SQDG (34:1) at $\mathrm{m} / \mathrm{z}$ 819.5, identified as SQDG (18:1/16:0), while the most abundant SQMG was detected at $m / z 555.3$ and corresponded to SQMG (16:0) (Fig. 1). Typical fragmentation of SQMG and SQDG species observed in LC-MS/MS spectra as $[\mathrm{M}-\mathrm{H}]^{-}$ions showed the product ion at $\mathrm{m} / \mathrm{z}, 225.0$, corresponding to the anion of the sulfoquinovosyl polar head group that confirmed the presence of sulfoglycolipids, as seen in the LC-MS/MS spectra of SQMG at $m / z 555.3$ (Fig. 1-B) and SQDG at $m / z 819.5$ (Fig. 1-D). Furthermore, product ions corresponding to the neutral loss of fatty acyl chains as carboxylic acid (RCOOH) can be identified and confirm the composition of fatty acyl chains. SQMG species exhibit only one neutral loss of one fatty acid $\mathrm{R}_{1} \mathrm{COOH}$ (El Baz et al. 2013; da Costa et al. 2015; Melo et al. 2015). LC-MS/MS spectrum of SQMG (16:0) at $\mathrm{m} / \mathrm{z} 555.3$ shows the neutral loss of palmitic acid (-16:0 $\left.\mathrm{R}_{1} \mathrm{COOH}, 256 \mathrm{Da}\right)$ that lead to the formation of the product ion at $m / z 299.0$ (Fig. 1-B). LC-MS/MS spectrum at $\mathrm{m} / z$ 819.5, corresponding to SQDG (18:1/16:0), shows the loss of two fatty acyl chains $\mathrm{R}_{1} \mathrm{COOH}$ and $\mathrm{R}_{2} \mathrm{COOH}$, that correspond to the neutral loss of $18: 1 \mathrm{RC}_{1} \mathrm{OOH}(-282 \mathrm{Da})$ and the neutral loss of palmitic acid 16:0 $\mathrm{R}_{2} \mathrm{COOH}(-256 \mathrm{Da}$ ) with formation of the product ions at $m / z 537.3$ and 563.3, respectively (Fig. 1-D).

275

The neutral molecula species monogalactosyldiacylglyceride

(MGDG), digalactosyldiacylglyceride

(DGDG) and their lyso forms, 
(DGMG), were identified in the positive $\mathrm{LC}-\mathrm{MS}$ spectra as $\left[\mathrm{M}+\mathrm{NH}_{4}\right]^{+}$ions. Overall 27

279

280

281

282

283

284

285

286

287

288

289

290

291

292

293

294

295

296

297

298

299

300

301

302

molecular species of MGDG, 13 of MGMG, 13 of DGDG and 9 of DGMG were identified (Table 3 and Fig. 2). The representative LC-MS spectra of MGDG and DGDG classes are shown in Fig. 2, as well as the LC-MS/MS spectra of the most abundant species of each class. The predominant MGDG were detected at $m / z$ 760.5. The DGDG were similarly predominate at $\mathrm{m} / \mathrm{z}, 932.6$ and 936.7 , representative spectrum in Fig. 2 concerns DGDG at $\mathrm{m} / z$ 932.6. The MGDG at $\mathrm{m} / z 760.5$ corresponds to MGDG (34:8) and was identified as MGDG (16:4/18:4), while the DGDG at $m / z$ 932.6 refers to DGDG (34:3) and was identified as DGDG (18:3/16:0). The typical fragmentation observed in the LC-MS/MS spectra of MGDG and DGDG species as $\left[\mathrm{M}+\mathrm{NH}_{4}\right]^{+}$ions allows to confirm the presence of these neutral glycolipids. LC-MS/MS spectrum of MGDG (34:8) at $m / z 760.5$ (Fig. 2-B) indicate the product ion at $m / z 563.4$, assigned as $[\mathrm{M}+\mathrm{NH} 4-$ $197]^{+}$, that results from combined loss of $\mathrm{NH}_{3}(-17 \mathrm{Da})$ and loss of a hexose (-180 Da) formed due to the cleavage of the sugar bond near the hemiacetal oxygen bond with proton transfer to render a diacylglycerol structure. Similarly, in the LC-MS/MS spectrum of DGDG (34:3) at $\mathrm{m} / z$ 932.6 (Fig. 2-D), we can observe the loss of the carbohydrate moiety (loss of $180+162 \mathrm{Da})$ combined with loss of $\mathrm{NH}_{3}(-17 \mathrm{Da})$, leading to the formation of the product ion at $m / z 573.5$, indicated as $\left[\mathrm{M}+\mathrm{NH}_{4}-359\right]^{+}$. The fatty acyl chains composition can be inferred by the presence of product ions corresponding to each fatty acyl group as an acylium ion plus $74(\mathrm{RCO}+74)$. These ions can be seen at $\mathrm{m} / \mathrm{z}$ 305.2 and 333.2 in MGDG spectrum (Fig. 2-B) and correspond to 16:4 and 18:4, respectively. In the case of DGDG spectrum (Fig. 2-D) the $[\mathrm{RCO}+74]^{+}$ions can be seen at $m / z 313.3$ and 335.3 and correspond to 16:0 and 18:3, respectively (Murphy 2015).

Betaine lipids identified in $U$. rigida included the diacylglyceroltrimethylhomoserine (DGTS) and its lyso form monoacylglyceroltrimethylhomoserine (MGTS). The DGTS 
and MGTS were identified in the LC-MS spectra as positive $[\mathrm{M}+\mathrm{H}]^{+}$ions. Overall 40 molecular species of DGTS and 17 molecular species of MGTS were identified (Table 4 and Fig. 3). The structural features of betaine lipids were confirmed through the identification of the typical product ions and fragmentation pathways observed in the LCMS/MS spectra. A representative LC-MS/MS spectrum of MGTS and DGTS is shown in Fig. 3-B and Fig. 3-C, corresponding to the MGTS (18:4) at $m / z, 494.3$ and DGTS (34:4), identified as DGTS (18:4/16:0) at $\mathrm{m} / z$ 732.6. Both LC-MS/MS spectra of MGTS (Fig. 3-B) and DGTS (Fig. 3-D) showed the typical reported ion of this class at $m / z 236.1$ corresponding to the combined loss of both fatty acids as keto derivatives $\left(\mathrm{R}_{1} \mathrm{CO}+\mathrm{R}_{2} \mathrm{CO}\right)$ (Melo et al. 2015; da Costa et al. 2018). The fatty acyl composition can be deducted by the losses of fatty acyl chains as acid $(-\mathrm{RCOOH})$ and ketene $(-\mathrm{R}=\mathrm{C}=\mathrm{O})$ derivatives. The ion at $m / z 236.1$ in LC-MS/MS spectrum of MGTS (18:4) (Fig. 3-B) also represents the loss of 18:4 fatty acyl chain as keto derivative (-258 Da). In its turn, the LC-MS/MS spectrum of DGTS (18:4/16:0) (Fig. 3-D) showed the ions at $\mathrm{m} / \mathrm{z} 474.4$ and 494.3 corresponding to the loss of fatty acyl chains as keto derivatives (-258 and -238 Da), matching to $18: 4$ and 16:0 fatty acids. Moreover, the ion at $\mathrm{m} / z, 456.4$ confirmed the presence of the fatty acid 18:4 since it corresponds to the loss of this fatty acyl chain as an acid derivative (-276 Da).

PLs classes identified in $U$. rigida included phosphatidylglycerol (PG), phosphatidylinositol (PI), phosphatidylethanolamine (PE), phosphatidylcholine (PC) and their lyso forms LPG, LPI, LPE and LPC. They were identified in negative mode as [M $-\mathrm{H}]^{-}$ions. Overall 5 molecular species of LPG, 17 of PG, 6 of PI and 1 of LPI were recognized (Table 5).

The LC-MS/MS spectra of PG (Fig. 4-A) and LPG species allowed to confirm their polar head by the presence of the product ion at $\mathrm{m} / z$ 171.0, corresponding to $\left[\mathrm{C}_{3} \mathrm{H}_{7} \mathrm{O}_{2} \mathrm{OPO}_{3} \mathrm{H}\right]$ 
- On the other hand, the polar head of PI (Fig. 4-B) and LPI is observed at $\mathrm{m} / \mathrm{z} 241.0$, corresponding to an inositol-1,2-cyclic phosphate anion $\left(\mathrm{C}_{6} \mathrm{H}_{10} \mathrm{O}_{5} \mathrm{PO}_{3}\right]^{-}$. The carboxylate anions $\mathrm{R}_{1} \mathrm{COO}^{-}$and $\mathrm{R}_{2} \mathrm{COO}^{-}$allowed the identification of fatty acyl chains (Murphy 2015).

LPE, PE, LPC and PC molecular species were identified in positive mode as $[\mathrm{M}+\mathrm{H}]^{+}$ ions. Overall, 7 molecular species of LPE, 3 of PE, 3 of LPC and 15 of PC were identified (Table 6). Typical loss of 141 Da was noted in LC-MS/MS spectra of $[\mathrm{M}+\mathrm{H}]^{+}$ions of LPE and PE, while the acyl chains were identified in negative mode by the presence of carboxylate $\mathrm{RCOO}^{-}$anions observed in the $\mathrm{LC}-\mathrm{MS} / \mathrm{MS}$ spectra of the respective $[\mathrm{M}-\mathrm{H}]^{-}$ ions. The LC-MS/MS spectra of $[\mathrm{M}+\mathrm{H}]^{+}$ions of LPC and PC showed the typical product ion of the polar head at $\mathrm{m} / \mathrm{z}$ 184.0, while the carboxylate $\mathrm{RCOO}^{-}$anions that allowed the identification of fatty acyl composition were observed in the LC-MS/MS spectra of the respective $\left[\mathrm{M}-\mathrm{CH}_{3} \mathrm{COO}\right]^{-}$ions (Murphy 2015).

\section{Discussion}

To the best knowledge of the authors, the present study represents the first in depth characterization of lipidomic signature of the green macroalgae $U$. rigida. $U$. rigida screened in the present work was produced in a land-based IMTA system, with this culture approach being considered as a sustainable and environmentally friendly approach to produce seaweeds and provide high grade safe biomass. When compared to the harvesting of seaweeds from the wild, this production system has as main the advantages the production of high biomass loads under controlled and replicable conditions, a less variable biochemical profile that allows product standardization, as well as the implementation of mandatory traceability protocols for seaweeds and seaweed-based-products targeting premium markets (Ridler et al. 2007; Chopin et al. 2012). Fatty acids profile identified was similar with that reported for the same species (Ak et al. 2014) and for other species belonging to the genus Ulva, namely Ulva lactuca, 
354 Ulva rotundata, Ulva clathrata and Ulva intestinalis (Fleurence et al. 1994; Peñarodríguez et al. 2011; van Ginneken et al. 2011; Rozentsvet and Nesterov 2012). As the PUFAs reported in the present study are essential FAs for humans, the macroalgae $U$. rigida can be an affordable dietary source of these FAs (Li et al. 2009; Cottin et al. 2011). There are several studies that defend an ideal $n-6 / n-3$ ratio. While $n-3$ PUFAs exhibit antiinflammatory and antioxidant activity, improve the cardiac system and prevent breast cancer (Mozaffarian et al. 2005; Siriwardhana et al. 2012; Fabian et al. 2015), n-6 PUFAs tend to promote tumor growth and inflammatory processes (Patterson et al. 2011). One of the important dietary factor in the obesity prevention is a balanced $n-6 / n-3$ ratio of 1 2/1 (Simopoulos 2016). Therefore, the consumption of $n$-6 FAs should be lower than $n$ 3, in order to avoid several diseases including depressive disorder (Okuyama et al. 1997; Husted and Bouzinova 2016). In addition, lower $n-6 / n-3$ ratio was associated with decreased risk of breast cancer in women (Simopoulos 2008). In this context, U. rigida presented a relative abundance of $n-6$ and $n-3$ PUFAs of $1.51 \%$ and $21.77 \%$, respectively. Therefore, its $n-6 / n-3$ ratio is lower than 1 , highlighting the potential health promoting properties of this macroalgae for human consumption. Although $n-6 / n-3$ ratios are known to vary between species and growth condition, to the authors best knowledge $U$. rigida farmed using a sustainable land based IMTA approach described in the present study displayed the lowest $n-6 / n-3$ ratio report so far for Ulva spp. (van Ginneken et al. 2011; Kendel et al. 2015). This finding confirms the added value of algal biomass originating from land-based IMTA, as a higher contents in $n-3$ fatty acids are commonly associated with health promoting benefits for consumers (Simopoulos 2002).

Identified FAs are esterified into lipid molecules such as glycolipids, betaine lipids and phospholipids (PLs). The glycolipids detected include sulfolipids and galactolipids which 
together represented the most abundant structural compounds of chloroplast membranes (Hölzl and Dörmann 2007) with up to 87 molecular species being identified in U. rigida.

There are several studies that demonstrated glycolipids bioactivity from different algae species, such as antiviral, antibacterial and antitumoral activity (Plouguerné et al. 2014; Blunt et al. 2016). Wang et al. (2007) described the antiviral activity attributed to SQDG (32:0) from the green macroalgae Caulerpa racemosa (Forsskål) J.Agardh, (1873). Furthermore, Baz et al. (2013) analyzed the SQMG (16:0) as antitumoral and antimicrobial activity Other authors demonstrated the inhibitory effect of SQDG and DGDG from the brown macroalgae Sargassum horneri (Turner) C.Agardh (1820) suggesting the use of these compounds like chemotherapy agents (Hossain et al. 2005). It is also reported that seaweeds with an abundant presence of PUFAs in their composition proved to display anti-inflammatory activity by inhibiting nitric oxide release by macrophages (Banskota et al. 2013; Lopes et al. 2014). Betaine lipids (DGTS and MGTS) represent a group of polar lipids low studied to date and few studies have characterized their profile in seaweeds (da Costa et al. 2015, 2017; Melo et al. 2015). Some species of DGTS identified in $U$. rigida have already been reported in green microalgae like Chlamydomonas reinhardtii P.A.Dangeard (1888) and Chlorarachniophytes (Vieler et al. 2007; Roche and Leblond 2010). It has been suggested that DGTS has the same function as PC due to their similar zwitterionic structure. Moreover, they are interchangeable with each other in their roles within the cell (Riekhof et al. 2005). Organisms that contain a high level of DGTS display either an absence of PC or its presence is very low (Dembitsky and Rezanka 1995; Kunzler and Eichenberger 1997). Furthermore, Ginneken et al. (2017) revealed that Ulva sp. uses a mechanism rarely reported in euckaryotes, as it applies the biochemical pathway to produce DGTS that can replace PC in seaweed cell 
wall (Klug and Benning 2001). It was suggested that the high DGTS/PC ratio occur

403

404

405

406

407

408

409

410

411

412

413

414

415

416

417

418

419

420

421

422

423

424

425

426 communlyin in species of the genus Ulva.

Regarding PLs, their beneficial effects have been studied since the early 1900s (Küllenberg de Gaudry et al. 2012). The positive effect of PLs is supported by several studies that showed an improvement of the pharmacokinetics of some drugs when associated with PLs compounds, and a reduction of side effects of some drugs when administered together, namely indomethacin (NSAID) (Dial et al. 2006; Lichtenberger et al. 2009). Their cytoprotectively effects and anti-fibrogenic potential have already been highlighted (Gundermann et al. 2011). Moreover, PLs from marine organisms have shown a remarkable effect in the regulation of the blood lipid profile in patients suffering from hyperlipidaemia (Bunea et al. 2004). PLs beneficial dietary effect is the result of their interaction with cellular membranes influencing a vast number of signaling processes and also the effect of their fatty acid composition. The great advantage of these molecules is related with the ability of their esterified $n-3$ FAs to compensate $n-3$ FA deficiency in a more efficient way than other n-3 FA supplements (e.g. as triacylglycerides or as free FAs). Thus, PLs from foodstuff are major supplies of $n-3$ PUFAs for living systems (Jannace et al. 1992). Furthermore, the antioxidant potential of PG found in U. rigida could be explored (Banskota et al. 2014).

Traditionally the study of algal lipids has targeted fatty acids analysis through GC-MS or GC-FID (Marshall et al. 2002). However, the overall information acquired through these techniques is limited and solely refers to fatty acids, which in living systems are mostly linked to polar lipids. In the last decade, with the advent of mass spectrometry, the commercialization of new devices with higher sensitivity, resolution and sample screening speed, such as Orbitrap ant Q-TOF instruments, allowed to gain a more in depth knowledge of lipids. The used of liquid chromatography (LC) online with mass 
spectrometry is nowadays an advanced and promising approach to study lipids in living systems. The LC-MS platforms allows to identify and quantify molecular structural details in one single run over very short periods of time (Maciel et al. 2016). In one LCMS run, more than two hundred lipid species from different lipid classes are routinely identified and quantified. Lipid species identification is based on the ions in MS and, in the case of high-resolution MS, through confirmation of mass accuracy. The structural details are confirmed by MS/MS data of each molecular species, namely through the analysis of typical ion fragments. In recent years, this lipidomic approach has been successfully used to unravel the lipidome of seaweeds (da Costa et al. 2015, 2017, 2018; Melo et al. 2015) and has become a powerful tool to screen for high value lipid species with potential biotechnological applications.

\section{Conclusion}

The mass spectrometry-based approach employed in the present study allowed the identification of 202 molecular species of polar lipids shared between glycolipids, betaine lipids and phospholipids, most of them confirmed by their fatty acids composition. The knowledge of lipid composition of $U$. rigida from a sustainable land-based IMTA system, comes to inspire future studies of valorization of this seaweed, as its aquaculture production under controlled conditions will continue to increase as it offers consumers a safer and more standardized product, from an organoleptically (industry communication) and biochemical point of view. Moreover, the present study may also serve to stimulate the consumption of $U$. rigida produced under controlled conditions, as its lipidome displays a number of molecular species with beneficial bioactive properties that may also foster new biotechnological applications. 
The authors are grateful to ALGAplus- Produção e Comércio de algas e seus derivados,

Lda. for supplying the seaweed samples. Thanks are due to Fundação para a Ciência e a

Tecnologia (FCT, Portugal), European Union, QREN, POPH, FEDER and COMPETE for funding the QOPNA research unit (FCT UID/QUI/00062/2013), to RNEM (LISBOA01-0145-FEDER-402-022125) for the Portuguese Mass Spectrometry Network, to

CESAM (UID/AMB/50017/2013) financed by Portuguese funds through the FCT/MEC and when applicable co-financed by FEDER under the PT2020 Partnership Agreement. Thanks are also due to FCT for the grants of Diana Lopes (SFRH/BD/119027/2016) and Felisa Rey (SFRH/BPD/115347/2016). Ana S.P. Moreira (BPD/UI51/5041/2017) and Elisabete da Costa (BPD/UI51/5042/2018) are grateful for the grants within framework of the project GENIALG - Genetic diversity exploitation for innovative macro-alga biorefinery (ANR-15-MRSE-0015) funded by European Union's Horizon 2020 Framework Programme. Tânia Melo is grateful for her Post-Doc grant (BPD/UI 51/5388/2017) funded by RNEM. This work is a contribution of the Marine Lipidomics Laboratory and was also supported by the Integrated Programme of SR\&TD "Smart Valorization of Endogenous Marine Biological Resources Under a Changing Climate" (Centro-01-0145-FEDER-000018), co-funded by Centro 2020 program, Portugal 2020, European Union, through the European Regional Development Fund.

\section{References}

Abreu M, Pereira R, Sassi J-F (2014) Marine Algae and the Global Food Industry. In:

Ak İ, Öztaşkent C, Özüdoğru Y, Göksan T (2014) Effect of sodium acetate and sodium 
nitrate on biochemical composition of green algae Ulva rigida . Aquac Int 23:1-12

Angell AR, Mata L, de Nys R, Paul NA (2016) The protein content of seaweeds: a universal nitrogen-to-protein conversion factor of five. J Appl Phycol 28:511-524

Banskota AH, Stefanova R, Sperker S, Lall SP, Craigie JS, Hafting JT, Critchley AT (2014) Polar lipids from the marine macroalga Palmaria palmata inhibit lipopolysaccharide-induced nitric oxide production in RAW264.7 macrophage cells. Phytochemistry 101:101-108

Banskota AH, Stefanova R, Sperker S, Melanson R, Osborne JA, O’Leary SJB (2013) Five new galactolipids from the freshwater microalga Porphyridium aerugineum and their nitric oxide inhibitory activity. J Appl Phycol 25:951-960

Barriga LGC, Ruvalcaba FS, Carmona GH, Briones ER, Herrera RMH (2017) Effect of seaweed liquid extracts from Ulva lactuca on seedling growth of mung bean (Vigna radiata). J Appl Phycol 29:2479-2488

Barrington K, Chopin T, Robinson S (2009) Integrated multi-trophic aquaculture (IMTA) in marine temperate waters. Integr Maric - A Glob Rev - FAO Fish Aquac Tech Pap N0 $5297-46$

Berri M, Slugocki C, Olivier M, Helloin E, Jacques I, Salmon H, Demais H, Le Goff M, Collen PN (2016) Marine-sulfated polysaccharides extract of Ulva armoricana green algae exhibits an antimicrobial activity and stimulates cytokine expression by intestinal epithelial cells. J Appl Phycol 28:2999-3008

Blunt JW, Copp BR, Keyzers RA, Munro MHG, Prinsep MR (2016) Marine natural products. Nat Prod Rep 33:382-431

Bolton J, Robertson-Andersson D, Shuuluka D, Kandjengo L (2008) Growing Ulva (Chlorophyta) in integrated systems as a commercial crop for abalone feed in South Africa: a SWOT analysis. J Appl Phycol 21:575-583 
Bunea R, El Farrah K, Deutsch L (2004) Evaluation of the effects of Neptune Krill Oil on the clinical course of hyperlipidemia. Altern Med Rev 9:420-428

Calder PC (2001) Polyunsaturated fatty acids, inflammation, and immunity. Lipids $36: 1007-1024$

Chopin T, Cooper JA, Reid G, Cross S, Moore C (2012) Open-water integrated multitrophic aquaculture: Environmental biomitigation and economic diversification of fed aquaculture by extractive aquaculture. Rev Aquac 4:209-220

Cottin SC, Sanders TA, Hall WL (2011) The differential effects of EPA and DHA on cardiovascular risk factors. Proc Nutr Soc 70:215-231

da Costa E, Azevedo V, Melo T, Rego AM, Evtuguin D V., Domingues P, Calado R, Pereira R, Abreu MH, Domingues MR (2018) High-Resolution Lipidomics of the Early Life Stages of the Red Seaweed Porphyra dioica. Molecules 23:1-20

da Costa E, Melo T, Moreira ASP, Alves E, Domingues P, Calado R, Abreu MH, Domingues MR (2015) Decoding bioactive polar lipid profile of the macroalgae Codium tomentosum from a sustainable IMTA system using a lipidomic approach. Algal Res 12:388-397

da Costa E, Melo T, Moreira ASP, Bernardo C, Helguero L, Ferreira I, Cruz MT, Rego AM, Domingues P, Calado R, Abreu MH, Domingues MR (2017) Valorization of Lipids from Gracilaria sp. through Lipidomics and Decoding of Antiproliferative and Anti-Inflammatory Activity. Mar Drugs 15:1-17

Dembitsky VM, Rezanka T (1995) Distribution of acetylenic acids and polar lipids in some aquatic bryophytes. Phytochemistry 40:93-97

Dial EJ, Doyen JR, Lichtenberger LM (2006) Phosphatidylcholine-associated nonsteroidal anti-inflammatory drugs (NSAIDs) inhibit DNA synthesis and the growth of colon cancer cells in vitro. Cancer Chemother Pharmacol 57:295-300 
527 Eitsuka T, Nakagawa K, Igarashi M, Miyazawa T (2004) Telomerase inhibition by

528

529

530

531

532

533

534

535

536

537

538

539

540

541

542

543

544

545

546

547

548

549

550

551 sulfoquinovosyldiacylglycerol from edible purple laver (Porphyra yezoensis). Cancer Lett 212:15-20

El Baz FK, El Baroty GS, Abd El Baky HH, Abd El Salam OI, Ibrahim EA (2013) Structural characterization and Biological Activity of Sulfolipids from selected Marine Algae. 64:561-571

Fabian CJ, Kimler BF, Hursting SD (2015) Omega-3 fatty acids for breast cancer prevention and survivorship. Breast Cancer Res. 17:1-11

Fleurence J, Gutbier G, Mabeau S, Leray C (1994) Fatty acids from 11 marine macroalgae of the French Brittany coast. J Appl Phycol 6:527-532

Ginzberg A, Cohen M, Sod-Moriah UA, Shany S, Rosenshtrauch A, Arad SM (2000) Chickens Fed with Biomass of the Red Microalga Porphyridium sp. Have Reduced Blood Cholesterol Level and Modified Fatty Acid Composition in Egg Yolk. J Appl Phycol 12:325-330

Gundermann KJ, Kuenker A, Kuntz E, Droździk M (2011) Activity of essential phospholipids (EPL) from soybean in liver diseases. Pharmacol. Reports 63:643659

Hardouin K, Bedoux G, Burlot AS, Donnay-Moreno C, Bergé JP, Nyvall-Collén P, Bourgougnon N (2016) Enzyme-assisted extraction (EAE) for the production of antiviral and antioxidant extracts from the green seaweed Ulva armoricana (Ulvales, Ulvophyceae). Algal Res 16:233-239

Holdt SL, Kraan S (2011) Bioactive compounds in seaweed: Functional food applications and legislation. J Appl Phycol 23:543-597

Hölzl G, Dörmann P (2007) Structure and function of glycoglycerolipids in plants and bacteria. Prog Lipid Res 46:225-243 
Hossain Z, Kurihara H, Hosokawa M, Takahashi K (2005) Growth inhibition and induction of differentiation and apoptosis mediated by sodium butyrate in Caco-2 cells with algal glycolipids. Vitr Cell Dev Biol 41:154-159

Husted KS, Bouzinova E V. (2016) The importance of $n-6 / n-3$ fatty acids ratio in the major depressive disorder. Med. 52:139-147

Jannace PW, Lerman RH, Santos JI, Vitale JJ (1992) Effects of oral soy phosphatidylcholine on phagocytosis, arachidonate concentrations, and killing by human polymorphonuclear leukocytes. Am J Clin Nutr 56:599-603

Kendel M, Wielgosz-collin G, Bertrand S, Roussakis C, Bourgougnon N, Bedoux G (2015) Lipid Composition, Fatty Acids and Sterols in the Seaweeds Ulva armoricana, and Solieria chordalis from Brittany (France): An Analysis from Nutritional, Chemotaxonomic, and Antiproliferative Activity Perspectives. Mar Drugs 13:5606-5628

Klug RM, Benning C (2001) Two enzymes of diacylglyceryl-O-4'-(N,N,N,trimethyl)homoserine biosynthesis are encoded by btaA and btaB in the purple bacterium Rhodobacter sphaeroides. Proc Natl Acad Sci U S A 98:5910-5915

Küllenberg de Gaudry D, Taylor L a, Schneider M, Massing U (2012) Health effects of dietary phospholipids. Lipids Health Dis 11:1-16

Kumari P, Kumar M, Gupta V, Reddy CRK, Jha B (2010) Tropical marine macroalgae as potential sources of nutritionally important PUFAs. Food Chem 120:749-757

Kunzler K, Eichenberger W (1997) Betaine lipids and zwitterionic phospholipids in plants and fungi. Phytochemistry 46:883-892

Lahaye M, Robic A (2007) Structure and function properties of Ulvan, a polysaccharide from green seaweeds. Biomacromolecules 8:1765-1774

Lawton RJ, Mata L, de Nys R, Paul NA (2013) Algal bioremediation of waste waters 
from land-based aquaculture using Ulva: selecting target species and strains. PLoS One 8:1-10

579

580

581

582

583

584

585

586

587

588

589

590

591

592

593

594

595

596

597

598

599

600

601

Leal MC, Munro MHG, Blunt JW, Puga J, Jesus B, Calado R, Rosa R, Madeira C (2013) Biogeography and biodiscovery hotspots of macroalgal marine natural products. Nat Prod Rep 30:1380-1390

Li MH, Robinson EH, Tucker CS, Manning BB, Khoo L (2009) Effects of dried algae Schizochytrium sp., a rich source of docosahexaenoic acid, on growth, fatty acid composition, and sensory quality of channel catfish Ictalurus punctatus. Aquaculture 292:232-236

Lichtenberger LM, Romero JJ, Dial EJ (2009) Gastrointestinal safety and therapeutic efficacy of parenterally administered phosphatidylcholine-associated indomethacin in rodent model systems. Br J Pharmacol 157:252-257

Lopes G, Daletos G, Proksch P, Andrade PB, Valentão P (2014) Anti-inflammatory potential of monogalactosyl diacylglycerols and a monoacylglycerol from the edible brown seaweed Fucus spiralis linnaeus. Mar Drugs 12:1406-1418

Maciel E, Leal MC, Lillebø AI, Domingues P, Domingues MR, Calado R (2016) Bioprospecting of marine macrophytes using MS-based lipidomics as a new approach. Mar. Drugs 14:1-28

Marinho G, Nunes C, Sousa Pinto I, Pereira R, Rema P, Valente L (2013) The IMTAcultivated Chlorophyta Ulva spp. as a sustainable ingredient in Nile tilapia (Oreochromis niloticus) diets. J Appl Phycol 25:1359-1367

Marshall JA, Nichols PD, Hallegraeff GM (2002) Chemotaxonomic survey of sterols and fatty acids in six marine raphidophyte algae. J Appl Phycol 14:255-265

McHugh DJ (2003) A Guide to the Seaweed Industry. In: FAO Fisheries Technical Paper. Rome, p 105 
Melo T, Alves E, Azevedo V, Martins AS, Neves B, Domingues P, Calado R, Abreu H, Domingues MR (2015) Lipidomics as a new approach for the bioprospecting of marine macroalgae - unraveling the polar lipid and fatty acid composition of Chondrus crispus. Algal Res 8:181-191

Mozaffarian D, Ascherio A, Hu FB, Stampfer MJ, Willett WC, Siscovick DS, Rimm EB (2005) Interplay between different polyunsaturated fatty acids and risk of coronary heart disease in men. Circulation 111:157-164

Msuya FE, Neori A (2008) Effect of water aeration and nutrient load level on biomass yield, $\mathrm{N}$ uptake and protein content of the seaweed Ulva lactuca cultured in seawater tanks. J Appl Phycol 20:1021-1031

Murphy RC (2015) Tandem Mass Spectrometry of Lipids. The Royal Society of Chemistry, University of Colorado Denver, Aurora, CO, USA

Naylor J (1976) Production, trade and utilization of seaweeds and seaweed products. FAO Fisheries Technical Paper 1-73

Neori A (2009) Essential role of seaweed cultivation in integrated multi-trophic aquaculture farms for global expansion of mariculture: an analysis. In: Nineteenth International Seaweed Symposium. Springer Netherlands, Dordrecht, pp 117-120

Ohta K, Mizushina Y, Hirata N, Takemura M, Sugawara F, Matsukage A, Yoshida S, Sakaguchi K (1998) Sulfoquinovosyldiacylglycerol, KM043, a new potent inhibitor of eukaryotic DNA polymerases and HIV-reverse transcriptase type 1 from a marine red alga, Gigartina tenella. Chem Pharm Bull (Tokyo) 46:684-6

Okuyama H, Kobayashi T, Watanabe S (1997) Carcinogenesis and Metastasis Are Affected by Dietary $n-6 / n-3$ Fatty Acids. In: Ohigashi H, Osawa T, Terao J, Watanabe S, Yoshikawa T (eds) Food Factors for Cancer Prevention. Springer Japan, Tokyo, pp 509-512 
Parveez AA, Ahamed, Rasheed UM, Noorani KPM, Reehana N, Santhoshkumar S, Imran YMM, Alharbi SN, Arunachalam C, Alharbi AS, Akbarsha MA, Thajuddin N (2017) In vitro antibacterial activity of MGDG-palmitoyl from Oscillatoria acuminata NTAPC05 against extended-spectrum $\beta$-lactamase producers. J Antibiot (Tokyo) 70:754-762

Patterson RE, Flatt SW, Newman VA, Natarajan L, Rock CL, Thomson CA, Caan BJ, Parker BA, Pierce JP (2011) Marine fatty acid intake is associated with breast cancer prognosis. J Nutr 141:201-206

Peña-rodríguez A, Mawhinney TP, Ricque-marie D, Cruz-suárez LE (2011) Chemical composition of cultivated seaweed Ulva clathrata ( Roth ) C . Agardh. Food Chem $129: 491-498$

Plouguerné E, da Gama BAP, Pereira RC, Barreto-Bergter E (2014) Glycolipids from seaweeds and their potential biotechnological applications. Front Cell Infect Microbiol 4:1-5

Ragonese C, Tedone L, Beccaria M, Torre G, Cichello F, Cacciola F, Dugo P, Mondello L (2014) Characterisation of lipid fraction of marine macroalgae by means of chromatography techniques coupled to mass spectrometry. Food Chem 145:932940

Rajauria G (2015) Seaweeds: A sustainable feed source for livestock and aquaculture. In: Seaweed Sustainability: Food and Non-Food Applications. Elsevier Inc., University College Dublin, Lyons Research Farm, Newcastle, Co. Dublin, Ireland, pp 389-420 Ridler N, Wowchuk M, Robinson B, Barrington K, Chopin T, Robinson S, Page F, Reid G, Szemerda M, Sewuster J, Boyne-Travis S (2007) Integrated Multi - Trophic Aquaculture (IMTA): A potential strategic choice for farmers. Aquac Econ Manag 11:99-110 
Riekhof WR, Andre C, Benning C (2005) Two enzymes, BtaA and BtaB, are sufficient for betaine lipid biosynthesis in bacteria. Arch Biochem Biophys 441:96-105

Roche SA, Leblond JD (2010) Betaine lipids in chlorarachniophytes. Phycol Res 58:298305

Roohinejad S, Koubaa M, Barba FJ, Saljoughian S, Amid M, Greiner R (2016) Application of seaweeds to develop new food products with enhanced shelf-life, quality and health-related beneficial properties. Food Res Int 99:1066-1083

Rozentsvet OA, Nesterov VN (2012) Lipids and fatty acids from Ulva intestinalis from estuaries of the caspian basin (elton region). Chem Nat Compd 48:544-547

Shpigel M, Guttman L, Shauli L, Odintsov V, Ben-Ezra D, Harpaz S (2017) Ulva lactuca from an Integrated Multi-Trophic Aquaculture (IMTA) biofilter system as a protein supplement in gilthead seabream (Sparus aurata) diet. Aquaculture 481:112-118

Simopoulos AP (2002) The importance of the ratio of omega-6 / omega-3 essential fatty acids. Biomed Pharmacother 56:365-379

Simopoulos AP (2016) An increase in the Omega-6/Omega-3 fatty acid ratio increases the risk for obesity. Nutrients $8: 1-17$

Simopoulos AP (2008) The importance of the omega-6/omega-3 fatty acid ratio in cardiovascular disease and other chronic diseases. Exp Biol Med 233:674-688

Siriwardhana N, Kalupahana NS, Moustaid-Moussa N (2012) Health Benefits of n-3 Polyunsaturated Fatty Acids. Eicosapentaenoic Acid and Docosahexaenoic Acid. Adv Food Nutr Res 65:211-222

Stengel D, Connan S, Popper Z (2011) Algal Chemodiversity and Bioactivity: Sources of Natural Variability and Implications for Commercial Application. Biotechnol Adv 29:483-501

Takahashi Y, Itoh K, Ishii M, Itabashi Y (2002) Induction of larval settlement and 
metamorphosis of the sea urchin Strongylocentrotus intermedius by glycoglycerolipids from the green alga Ulvella lens. 140:763-771

van Ginneken V, Gittenberger A, Rensing M, de Vries E, Peeters ETHM, Verheij E (2017) Seaweed Competition: Ulva sp. has the Potential to Produce the Betaine Lipid Diacylglyceryl-O-4' - ( N, N, N , -Trimethyl ) Homoserine ( DGTS ) in Order to Replace Phosphatidylcholine ( PC ) Under Phosphate-Limiting Conditions in the P-Limited. Oceanogr Fish 2:1-10

van Ginneken VJ, Helsper JP, de Visser W, van Keulen H, Brandenburg WA (2011) Polyunsaturated fatty acids in various macroalgal species from north Atlantic and tropical seas. Lipids Health Dis 10:1-8

Vieler A, Wilhelm C, Goss R, Süß R, Schiller J (2007) The lipid composition of the unicellular green alga Chlamydomonas reinhardtii and the diatom Cyclotella meneghiniana investigated by MALDI-TOF MS and TLC. Chem Phys Lipids $150: 143-155$

Wang H, Li YL, Shen WZ, Rui W, Ma XJ, Cen YZ (2007) Antiviral activity of a sulfoquinovosyldiacylglycerol (SQDG) compound isolated from the green alga Caulerpa racemosa. Bot Mar 50:185-190

Wijesekara I, Lang M, Marty C, Gemin M-P, Boulho R, Douzenel P, Wickramasinghe I, Bedoux G, Bourgougnon N (2017) Different extraction procedures and analysis of protein from Ulva sp. in Brittany, France. J Appl Phycol 29:2503-2511 
Figure 1. LC-MS spectra in negative ion mode of SQMG (A) and SQDG (C) classes

705

706

707

708

709

710

711

712

713

714

715

716

717

718

719

720

721

722

723

724

725

726 identified as $[\mathrm{M}-\mathrm{H}]^{-}$ions. LC-MS/MS spectra of the $[\mathrm{M}-\mathrm{H}]^{-}$ions of the most abundant species of SQMG at $m / z, 555.3$ (B) and SQDG at $m / z 819.5$ (D).

Figure 2. LC-MS spectra in positive ion mode of MGDG (A) and DGDG (C) classes identified as $\left[\mathrm{M}+\mathrm{NH}_{4}\right]^{+}$. LC-MS/MS spectra of the $\left[\mathrm{M}+\mathrm{NH}_{4}\right]^{+}$ions of the most abundant specie of MGDG at $m / z 760.6$ (B) and DGDG at $m / z 932.5$ (D). The ions group assigned with symbol (*) are a background.

Figure 3. LC-MS spectra in positive mode of MGTS (A) and DGTS (C) classes identified as $[\mathrm{M}+\mathrm{H}]^{+}$ions. LC-MS/MS spectra of the $[\mathrm{M}+\mathrm{H}]^{+}$ions of the most abundant specie of MGTS at $m / z 494.3$ (B) and DGTS at $m / z 732.6(\mathrm{C})$.

Figure 4. LC-MS/MS spectrum in negative mode of PG (34:4) specie at $\mathrm{m} / z, 741.5$ (A) and PI (34:3) specie at $m / z 831.5$ (B) identified as $[\mathrm{M}-\mathrm{H}]^{-}$ions.

Table 1. Fatty acid profile of $U$. rigida sustainably produced under IMTA conditions, expressed as relative abundance (\%). Values are means of seven samples \pm standard deviation (SD).

Table 2. Molecular species of SQDGs and SQMGs identified by HILIC-ESI-MS as negative $[\mathrm{M}-\mathrm{H}]^{-}$ions. Identification as sulfoglycolipids and fatty acyl composition was confirmed by the analysis of the LC-MS/MS spectra of each $[\mathrm{M}-\mathrm{H}]^{-}$ion. C represents 
the total number of carbon atoms and $\mathrm{N}$ the total number of double bonds on the fatty acyl chains. The most abundant species are marked in bold.

Table 3. Molecular species of MGDG, MGMG, DGDG and DGMG identified by HILIC-ESI-MS as positive $\left[\mathrm{M}+\mathrm{NH}_{4}\right]^{+}$ions. Identification as galactoglycerolipids and fatty acyl composition was confirmed by the analysis of the LC-MS/MS spectra of each $\left[\mathrm{M}+\mathrm{NH}_{4}\right]^{-}$ion. $\mathrm{C}$ represents the total number of carbon atoms and $\mathrm{N}$ the total number of double bonds on the fatty acyl chains. The most abundant species are marked in bold.

Table 4. Molecular species of DGTS and MGTS identified by HILIC-ESI-MS as positive $[\mathrm{M}+\mathrm{H}]^{+}$ions. Identification as betaines and fatty acyl composition was confirmed by the analysis of the LC-MS/MS spectra of each $[\mathrm{M}+\mathrm{H}]^{+}$ion. $\mathrm{C}$ represents the total number of carbon atoms and $\mathrm{N}$ the total number of double bonds on the fatty acyl chains. The most abundant species are marked in bold.

Table 5. Molecular species of LPG, PG, LPI, PI identified by HILIC-ESI-MS as negative $[\mathrm{M}-\mathrm{H}]^{-}$ions. Identification of different PL classes and fatty acyl composition was confirmed by the analysis of the LC-MS/MS spectra of each $[\mathrm{M}-\mathrm{H}]^{-}$ion. $\mathrm{C}$ represents the total number of carbon atoms and $\mathrm{N}$ the total number of double bonds on the fatty acyl chains. The most abundant species are marked in bold.

Table 6. Molecular species of LPE, PE, LPC and PC identified by HILIC-ESI-MS as positive $[\mathrm{M}+\mathrm{H}]^{+}$ions. Identification of PL class was confirmed by the analysis of the LC-MS/MS spectra of each $[\mathrm{M}+\mathrm{H}]^{+}$ion. Identification of fatty acyl composition was performed by the analysis of the LC-MS/MS spectra of respective $[\mathrm{M}-\mathrm{H}]^{-}$ions for LPE 

number of carbon atoms and $\mathrm{N}$ the total number of double bonds on the fatty acyl chains.

754 
756

757

A

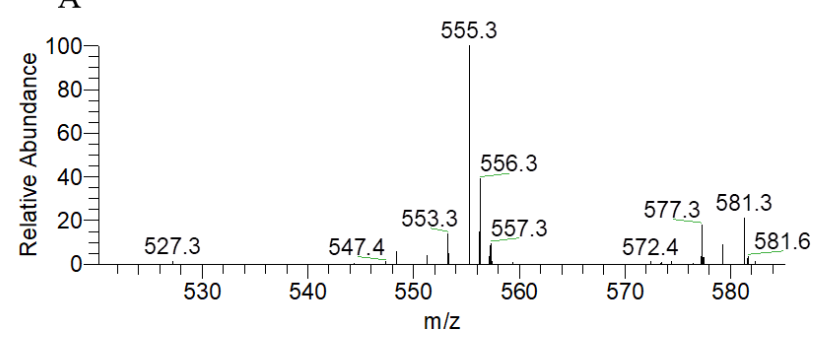

758

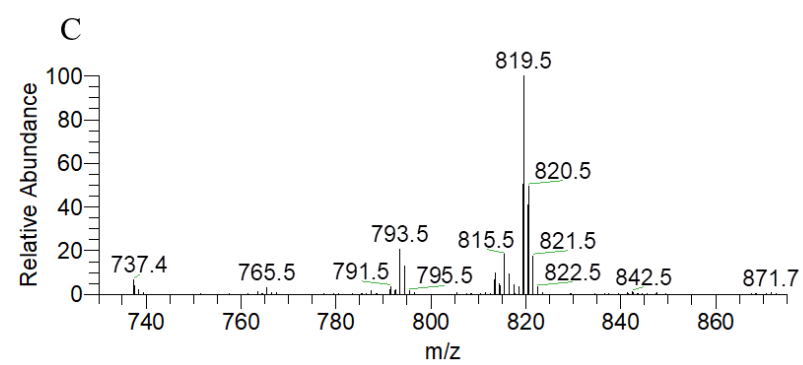

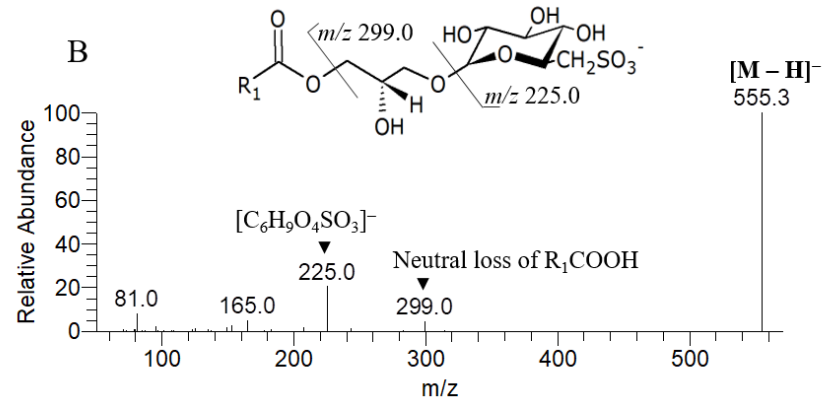
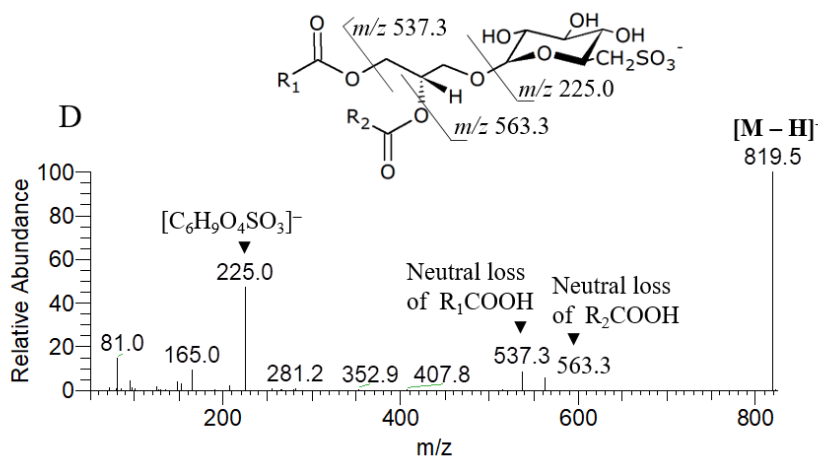

759

760

Figure 1.

761

762

763

764

765 
A

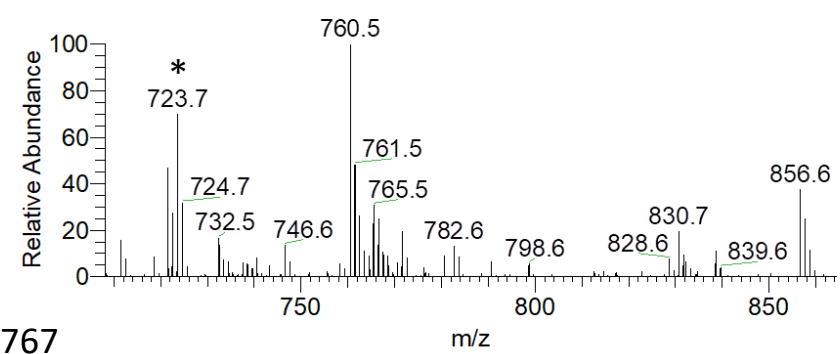

768

\section{C}

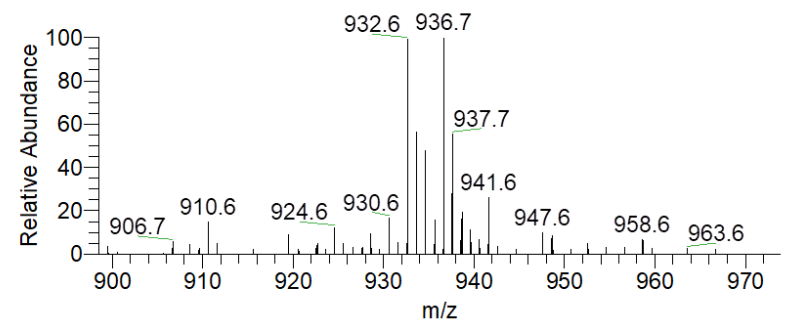

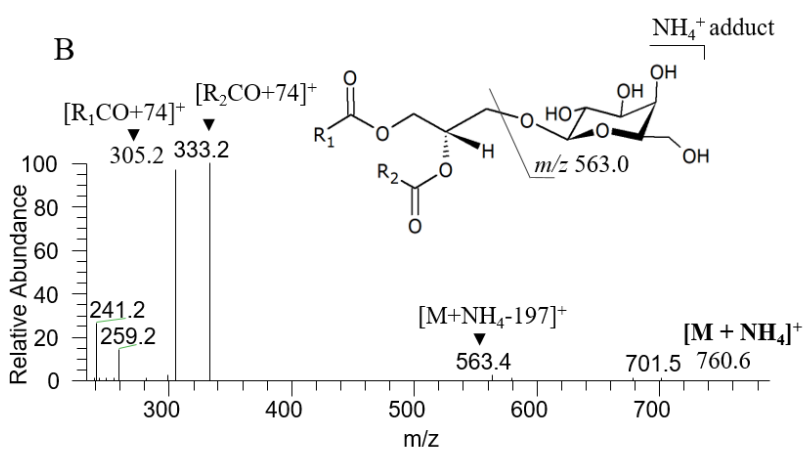

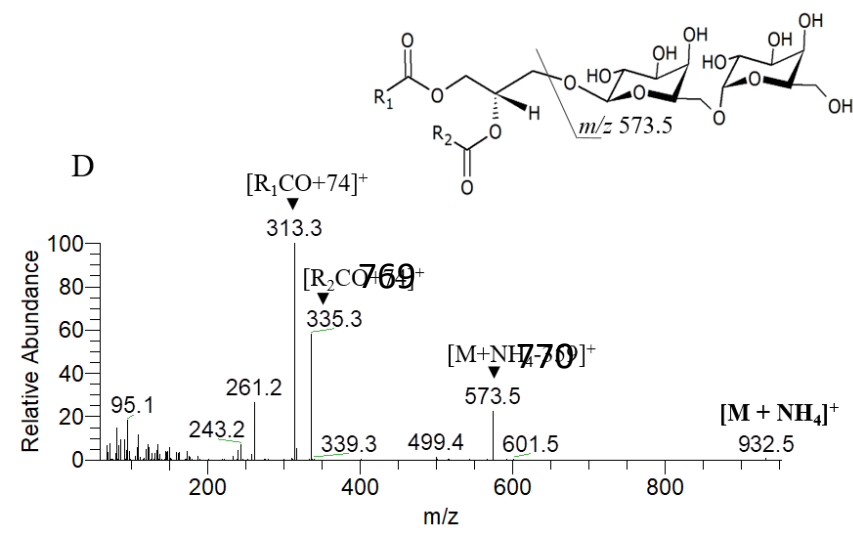

771

772

773

Figure 2.

774

775

776

777 


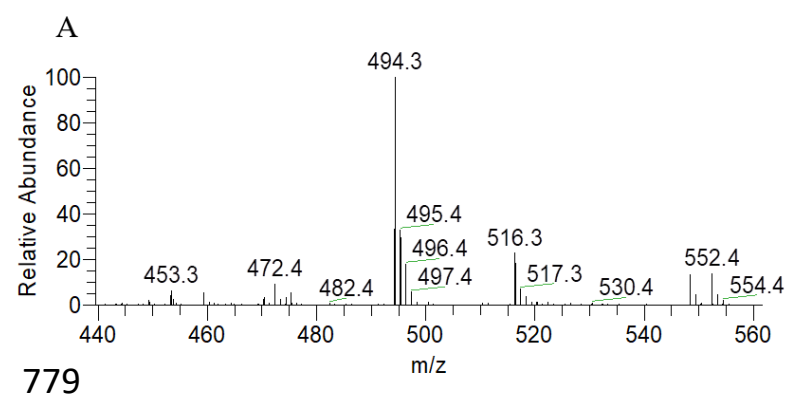

780

$\mathrm{C}$

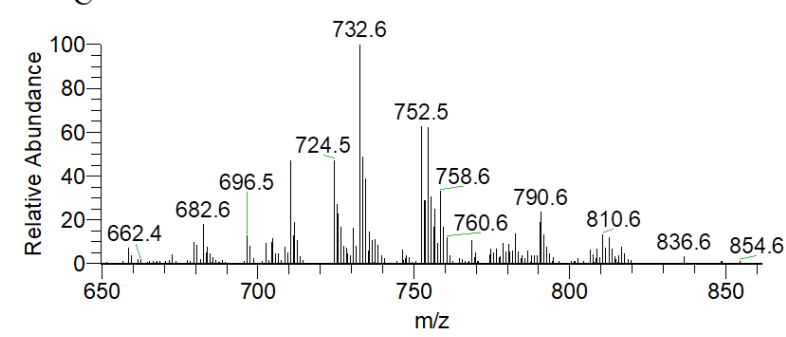

781

782

783

784

785

786

787

788

789

790

791

792

793

794

795

796

797

798

799

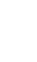

.

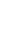

\section{7}

89

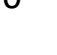
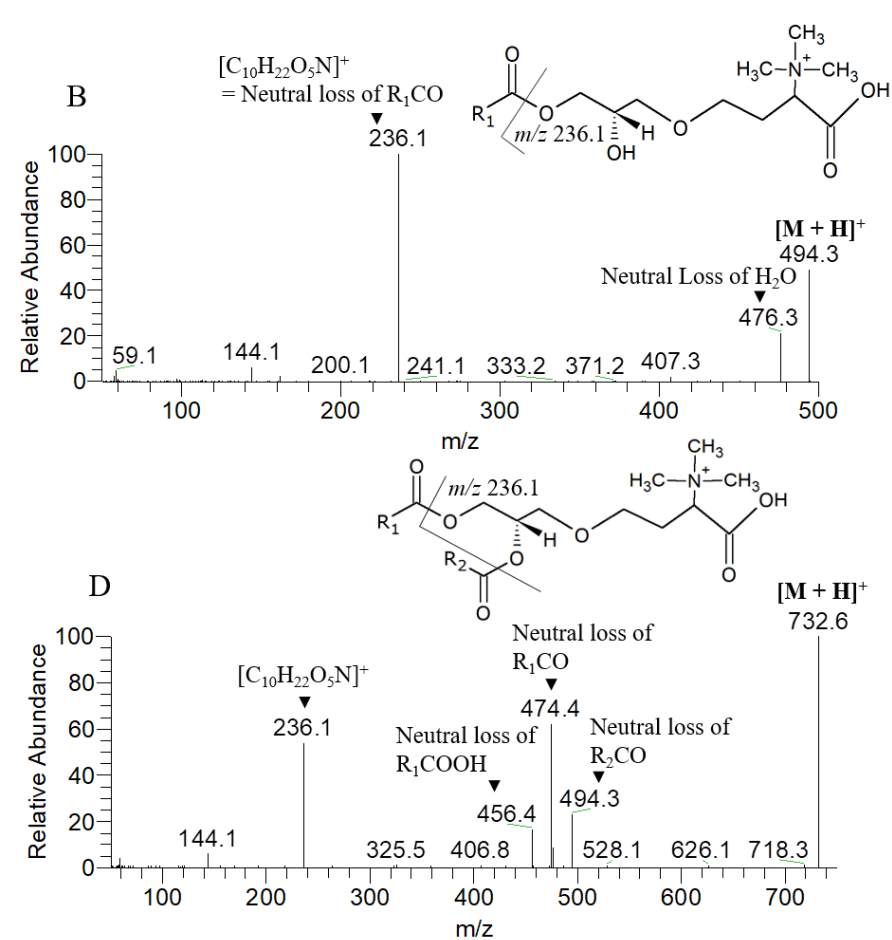

Figure 3. 

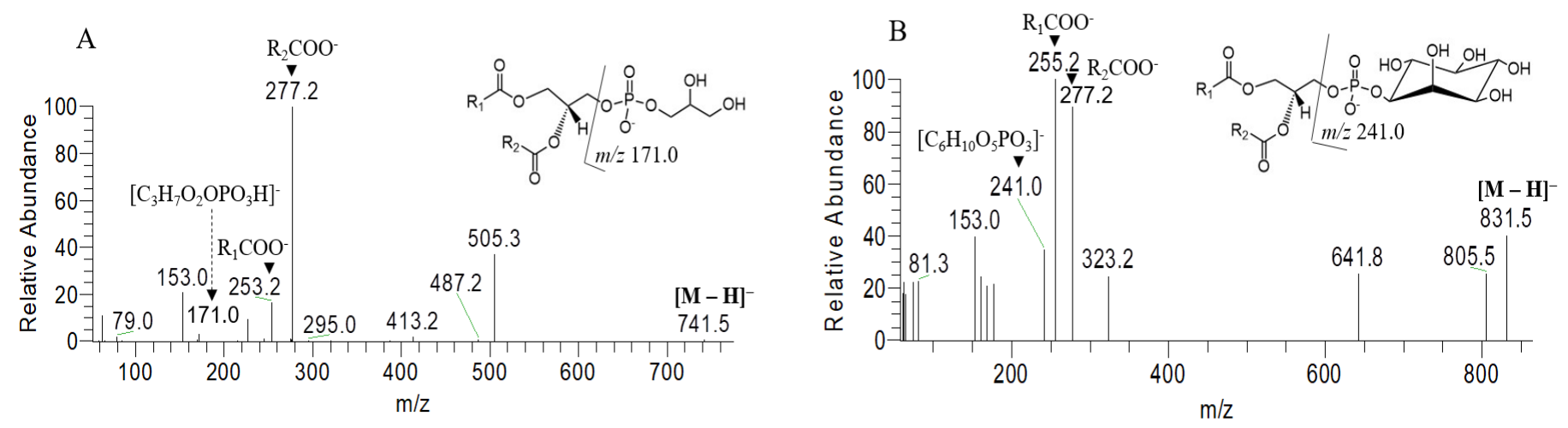

800

801

Figure 4.

802

803

804

805

806

807

808

809

810

811

812

813

814

815

816

817

818

819

820

821

822

823

Table 1. 
826

827

828

829

830

831

832

833

834

835

836

837

838

839

840

841

842

843

844

845

846

847

848

849

850

851

852

853

854

851

85
Fatty acids Relative abundance $(\%) \pm$ SD

\begin{tabular}{ll}
\hline $14: 0$ & $1.33 \pm 0.21$ \\
$16: 0$ & $43.41 \pm 0.75$ \\
$16: 1(n-7)$ & $1.39 \pm 0.12$ \\
$16: 1(n-9)$ & $1.76 \pm 0.16$ \\
$16: 4(n-3)$ & $3.76 \pm 0.17$ \\
$18: 0$ & $19.30 \pm 1.64$ \\
$18: 1$ & $8.56 \pm 1.21$ \\
$18: 2(n-6)$ & $1.21 \pm 0.10$ \\
$18: 3(n-6)$ & $0.29 \pm 0.04$ \\
$18: 3(n-3)$ & $4.45 \pm 0.22$ \\
$18: 4(n-3)$ & $8.82 \pm 0.40$ \\
$20: 4(n-3)$ & $0.65 \pm 0.06$ \\
$20: 5(n-3)$ & $0.84 \pm 0.10$ \\
$22: 0$ & $0.46 \pm 0.08$ \\
$22: 5(n-3)$ & $3.76 \pm 0.54$ \\
$\Sigma$ SFAs & $64.50 \pm 2.10$ \\
$\Sigma$ MUFAs & $11.71 \pm 0.78$ \\
$\Sigma$ PUFAs & $23.78 \pm 1.33$ \\
$\Sigma(n-3)$ & $22.28 \pm 1.22$ \\
$\Sigma(n-6)$ & $1.50 \pm 0.13$ \\
\hline
\end{tabular}

3

4

5

48

850

Table 2. 


\begin{tabular}{|c|c|c|c|c|c|}
\hline $\begin{array}{l}{[\mathrm{M}-\mathrm{H}]^{-}} \\
\mathrm{m} / \mathrm{z}\end{array}$ & $\begin{array}{l}\text { Lipid Species } \\
(\mathrm{C}: \mathrm{N})\end{array}$ & Fatty Acyl Chains & $\begin{array}{l}{[\mathbf{M}-\mathbf{H}]^{-}} \\
m / z\end{array}$ & $\begin{array}{l}\text { Lipid Species } \\
(\mathrm{C}: \mathrm{N})\end{array}$ & Fatty Acyl Chains \\
\hline 527.3 & SQMG $(14: 0)^{a}$ & & 805.5 & SQDG (33:1) & $17: 1 / 16: 0$ \\
\hline 553.3 & $\operatorname{SQMG}(16: 1)$ & $16: 1$ & $807.5^{\mathrm{a}}$ & SQDG (34:7) & \\
\hline 555.3 & SQMG (16:0) & $16: 0$ & 811.4 & SQDG (34:5) & 20:5/14:0 \\
\hline 577.3 & $\operatorname{SQMG~(18:3)}$ & $18: 3$ & 813.5 & SQDG (34:4) & $18: 4 / 16: 0$ \\
\hline 581.3 & $\operatorname{SQMG}(18: 1)$ & $18: 1$ & 815.5 & SQDG (34:3) & $18: 3 / 16: 0$ \\
\hline 737.5 & SQDG $(28: 0)$ & $14: 0 / 14: 0$ and $12: 0 / 16: 0$ & 819.5 & SQDG (34:1) & 18:1/16:0 \\
\hline 763.5 & SQDG (30:1) & $14: 0 / 16: 1$ & 839.5 & SQDG (36:5) & $20: 5 / 16: 0$ \\
\hline 765.5 & SQDG (30:0) & $14: 0 / 16: 0$ & 841.5 & SQDG (36:4) & $20: 4 / 16: 0$ and $18: 1 / 18: 3$ \\
\hline 785.5 & SQDG (32:4) & $16: 4 / 16: 0$ and $14: 0 / 18: 4$ & 843.5 & SQDG (36:3) & $20: 3 / 16: 0$ \\
\hline 787.5 & SQDG (32:3) & $14: 0 / 18: 3$ and $16: 3 / 16: 0$ & 845.5 & SQDG $(36: 2)^{b}$ & \\
\hline 789.5 & SQDG (32:2) & $18: 2 / 14: 0$ & 847.5 & SQDG $(36: 1)$ & $20: 1 / 16: 0$ and $18: 0 / 18: 1$ \\
\hline 791.5 & SQDG (32:1) & $16: 1 / 16: 0$ and $18: 1 / 14: 0$ & 867.5 & SQDG (38:5) & $22: 5 / 16: 0$ \\
\hline 793.5 & SQDG (32:0) & $16: 0 / 16: 0$ & & & \\
\hline
\end{tabular}

${ }^{\mathrm{a}}$ Molecular specie identified only by retention time and mass accuracy calculation.

${ }^{\mathrm{b}}$ Molecular species identified only by retention time, mass accuracy calculation and typical product ion at $m / z 225.0$

860

861

862

863

864

865

866

867

868

869

870

871

872

873

874

875

876

877

Table 3. 


\begin{tabular}{|c|c|c|c|c|c|}
\hline $\begin{array}{l}\left.\mathrm{M}+\mathrm{NH}_{4}\right]^{+} \\
\mathrm{m} / \mathrm{z}\end{array}$ & $\begin{array}{l}\text { Lipid Species } \\
\text { (C:N) }\end{array}$ & Fatty Acyl Chains & $\begin{array}{l}{\left[\mathrm{M}+\mathrm{NH}_{4}\right]^{+}} \\
m / z\end{array}$ & $\begin{array}{l}\text { Lipid Species } \\
\text { (C:N) }\end{array}$ & Fatty Acyl Chains \\
\hline 502.3 & MGMG (16:4) & $16: 4$ & 800.6 & MGDG (36:2) ${ }^{\mathrm{a}}$ & \\
\hline 504.3 & MGMG (16:3) & $16: 3$ & 792.5 & MGDG (36:6) & $18: 3 / 18: 3$ and $18: 4 / 18: 2$ \\
\hline 506.3 & MGMG (16:2) & $16: 2$ & 796.6 & MGDG (36:4) a & \\
\hline 508.3 & MGMG (16:1) & $16: 1$ & 826.6 & MGDG (38:3) a & \\
\hline 510.4 & $\operatorname{MGMG}(16: 0)^{\mathrm{a}}$ & & 828.7 & $\operatorname{MGDG}(38: 2)^{\mathrm{a}}$ & \\
\hline 530.3 & MGMG (18:4) a & & 830.7 & MGDG $(38: 1)^{\mathrm{a}}$ & \\
\hline 532.4 & $\operatorname{MGMG}(18: 3)^{\mathrm{a}}$ & & 854.7 & MGDG (40:3) ${ }^{\mathrm{a}}$ & \\
\hline 534.4 & MGMG (18:2) a & & 856.7 & $\operatorname{MGDG}(40: 2)^{\mathrm{a}}$ & \\
\hline 536.4 & $\operatorname{MGMG}(18: 1)^{\mathrm{a}}$ & & 858.7 & $\operatorname{MGDG}(40: 1)^{\mathrm{a}}$ & \\
\hline 556.4 & $\operatorname{MGMG}(20: 5)^{\mathrm{a}}$ & & 644.4 & $\operatorname{DGMG}(14: 0)^{\mathrm{a}}$ & \\
\hline 558.4 & MGMG (20:4) ${ }^{a}$ & & 664.4 & $\operatorname{DGMG}(16: 4)^{\mathrm{a}}$ & \\
\hline 584.4 & MGMG (22:5) ${ }^{\mathrm{a}}$ & & 666.4 & $\operatorname{DGMG}(16: 3)^{\mathrm{a}}$ & \\
\hline 592.4 & $\operatorname{MGMG}(22: 1)^{\mathrm{a}}$ & & 668.4 & $\operatorname{DGMG}(16: 2)^{\mathrm{a}}$ & \\
\hline 712.5 & $\operatorname{MGDG}(30: 4)^{\mathrm{a}}$ & & 670.4 & DGMG (16:1) & $16: 1$ \\
\hline 714.4 & $\operatorname{MGDG}(30: 3)^{\mathrm{a}}$ & & 672.4 & DGMG (16:0) & $16: 0$ \\
\hline 732.5 & MGDG (32:8) & $16: 4 / 16: 4$ & 692.4 & DGMG (18:4) a & \\
\hline 734.5 & MGDG (32:7) & $16: 3 / 16: 4$ & 694.4 & $\operatorname{DGMG}(18: 3)^{\mathrm{a}}$ & \\
\hline 736.5 & MGDG (32:6) & $16: 2 / 16: 4$ and $16: 3 / 16: 3$ & 746.4 & $\operatorname{DGMG}(22: 5)^{\mathrm{a}}$ & \\
\hline 738.5 & $\operatorname{MGDG}(32: 5)^{\mathrm{a}}$ & & 894.5 & $\operatorname{DGDG}(32: 8)^{\mathrm{a}}$ & \\
\hline 740.5 & MGDG (32:4) & $16: 4 / 16: 0$ and $16: 1 / 16: 3$ & 908.6 & DGDG (32:1) & $16: 1 / 16: 0$ and $18: 1 / 14: 0$ \\
\hline 742.5 & MGDG (32:3) & $16: 3 / 16: 0$ and $18: 3 / 14: 0$ & 910.6 & DGDG (32:0) & $16: 0 / 16: 0$ \\
\hline 748.6 & MGDG (32:0) & $16: 0 / 16: 0$ & 922.6 & DGDG $(34: 8)^{a}$ & \\
\hline 760.5 & MGDG (34:8) & $18: 4 / 16: 4$ & 924.6 & $\operatorname{DGDG}(34: 7)^{\mathrm{a}}$ & \\
\hline 764.5 & $\operatorname{MGDG}(34: 6)^{\mathrm{a}}$ & & 926.6 & DGDG $(34: 6)^{a}$ & \\
\hline 766.6 & MGDG (34:5) & $18: 1 / 16: 4$ & 928.6 & $\operatorname{DGDG}(34: 5)^{\mathrm{a}}$ & \\
\hline 768.6 & MGDG (34:4) & 18:4/16:0 and 18:3/16:1 & 930.6 & DGDG $(34: 4)^{\mathrm{a}}$ & \\
\hline 770.6 & MGDG (34:3) & 18:3/16:0 and 18:2/16:1 & 932.6 & DGDG (34:3) & $18: 3 / 16: 0$ \\
\hline 774.6 & MGDG (34:1) & 18:1/16:0 & 934.6 & DGDG (34:2) & $18: 2 / 16: 0$ \\
\hline 786.5 & $\operatorname{MGDG}(36: 9)^{\mathrm{a}}$ & & 936.7 & DGDG (34:1) & $18: 1 / 16: 0$ \\
\hline 788.5 & MGDG (36:8) & $18: 4 / 18: 4$ and $20: 5 / 16: 3$ & 956.6 & DGDG $(36: 5)^{\mathrm{a}}$ & \\
\hline 790.5 & MGDG (36:7) & $18: 4 / 18: 3$ and $20: 3 / 16: 4$ & 958.6 & DGDG (36:4) & $18: 3 / 18: 1$ \\
\hline
\end{tabular}




\begin{tabular}{|c|c|c|c|c|c|}
\hline $\begin{array}{l}{[\mathrm{M}+\mathrm{H}]^{+}} \\
\mathrm{m} / z\end{array}$ & $\begin{array}{l}\text { Lipid Species } \\
(\mathrm{C}: \mathrm{N})\end{array}$ & Fatty Acyl Chains & $\begin{array}{l}{[\mathrm{M}+\mathrm{H}]^{+}} \\
\mathrm{m} / z\end{array}$ & $\begin{array}{l}\text { Lipid Species } \\
\text { (C:N) }\end{array}$ & Fatty Acyl Chains \\
\hline 446.3 & MGTS (14:0) & 14:0 & 724.6 & DGTS (34:8) & $16: 4 / 18: 4$ \\
\hline 464.3 & MGTS (16:3) & $16: 3$ & 726.6 & DGTS (34:7) & $16: 4 / 18: 3$ \\
\hline 466.3 & MGTS (16:4) & $16: 4$ & 728.5 & DGTS (34:6) & $16: 2 / 18: 4$ \\
\hline 470.3 & MGTS (16:2) & $16: 2$ & 730.6 & DGTS (34:5) & $16: 1 / 18: 4$ and $16: 2 / 18: 3$ \\
\hline 472.4 & $\operatorname{MGTS}(16: 1)$ & $16: 1$ & 732.6 & DGTS (34:4) & $16: 0 / 18: 4$ \\
\hline 474.4 & MGTS (16:0) & $16: 0$ & $734.6^{*}$ & DGTS (34:3) & $16: 0 / 18: 3$ \\
\hline $492.3^{*}$ & MGTS (18:5) & $18: 5$ & 736.6 & DGTS (34:2) & $16: 0 / 18: 2$ and $16: 1 / 18: 1$ \\
\hline 494.3 & MGTS (18:4) & $18: 4$ & 738.6 & DGTS (34:1) & 16:0/18:1 \\
\hline 496.4 & MGTS (18:3) & $18: 3$ & 746.6 & DGTS (35:4) & $17: 0 / 18: 4$ \\
\hline 498.4 & MGTS (18:2) & $18: 2$ & 750.6 & DGTS (36:9) & $18: 4 / 18: 5$ \\
\hline 500.4 & MGTS (18:1) & $18: 1$ & 752.5 & DGTS $(36: 8)$ & $18: 4 / 18: 4$ \\
\hline 502.4 & MGTS (18:0) & 18:0 & $754.6^{*}$ & DGTS (36:7) & $18: 3 / 18: 4$ \\
\hline 520.4 & MGTS (20:5) & $20: 5$ & $756.6^{*}$ & DGTS (36:6) & $18: 3 / 18: 3$ and $18: 2 / 18: 4$ \\
\hline 522.4 & MGTS (20:4) & $20: 4$ & $758.6^{*}$ & DGTS (36:5) & 18:1/18:4 \\
\hline 524.4 & MGTS (20:3) & $20: 3$ & 760.6 & DGTS $(36: 4)^{\mathrm{a}}$ & \\
\hline 530.4 & MGTS (20:0) & 20:0 & 762.6 & DGTS (36:3) & 18:1/18:2 \\
\hline 548.4 & MGTS (22:5) & $22: 5$ & 764.6 & DGTS (36:2) & 18:1/18:1 \\
\hline 558.5 & MGTS (22:0) & $22: 0$ & 776.6 & $\operatorname{DGTS}(38: 10)^{\mathrm{a}}$ & \\
\hline 656.5 & DGTS (28:0) & 14:0/14:0 & 778.6 & DGTS (38:9) & $16: 4 / 22: 5$ and $20: 5 / 18: 4$ \\
\hline 676.5 & DGTS $(30: 4)^{\mathrm{a}}$ & & $780.6 *$ & DGTS (38:8) & $20: 4 / 18: 4$ \\
\hline 682.6 & DGTS (30:1) & $14: 0 / 16: 1$ & $782.6^{*}$ & DGTS (38:7) & $20: 4 / 18: 3$ and $20: 3 / 18: 4$ \\
\hline 684.6 & DGTS (30:0) & $16: 0 / 14: 0$ & 784.6 & DGTS (38:6) & $20: 2 / 18: 4$ and $16: 1 / 22: 5$ \\
\hline 700.6 & DGTS (32:6) & $16: 2 / 16: 4$ & 786.6 & DGTS (38:5) & $16: 0 / 22: 5$ \\
\hline 702.6 & $\operatorname{DGTS}(32: 5)^{\mathrm{a}}$ & & $808.6^{*}$ & DGTS (40:8) & $22: 5 / 18: 3$ \\
\hline 704.5 & DGTS (32:4) & 14:0/18:4 & 812.6 & DGTS (40:6) & 22:5/18:1 \\
\hline 706.6 & DGTS (32:3) & $16: 1 / 16: 2$ & 816.7 & DGTS (40:4) & $22: 0 / 18: 4$ \\
\hline 708.6 & DGTS (32:2) & $16: 0 / 16: 2$ and $16: 1 / 16: 1$ & 830.6 & $\operatorname{DGTS}(42: 11)^{\mathrm{a}}$ & \\
\hline 710.6 & DGTS (32:1) & 16:0/16:1 and 14:0/18:1 & 832.6 & DGTS (42:10) & $22: 5 / 20: 5$ \\
\hline 712.6 & DGTS (32:0) & $16: 0 / 16: 0$ & 860.6 & DGTS (44:10) & $22: 5 / 22: 5$ \\
\hline
\end{tabular}

${ }^{a}$ Molecular species identified only by retention time and mass accuracy calculation.

* Ion with contribution of sodium adduct $[\mathrm{M}+\mathrm{Na}]^{+}$of DGTS observed as $[\mathrm{M}+\mathrm{H}]^{+}$with mass difference of $22 \mathrm{Da}$.

895

896

897

898

899

900

901

902

903

Table 5. 


\begin{tabular}{|c|c|c|c|c|c|}
\hline $\begin{array}{l}{[\mathbf{M}-\mathbf{H}]^{-}} \\
m / z\end{array}$ & $\begin{array}{l}\text { Lipid Species } \\
(\mathrm{C}: \mathrm{N})\end{array}$ & Fatty Acyl Chains & $\begin{array}{l}{[\mathbf{M}-\mathbf{H}]^{-}} \\
m / z\end{array}$ & $\begin{array}{l}\text { Lipid Species } \\
(\mathrm{C}: \mathrm{N})\end{array}$ & Fatty Acyl Chains \\
\hline 481.3 & LPG (16:1) & $16: 1$ & 747.5 & PG (34:1) & $18: 1 / 16: 0$ and $16: 1 / 18: 0$ \\
\hline 483.3 & LPG (16:0) & $16: 0$ & 749.5 & PG $(34: 0)$ & $18: 0 / 16: 0$ \\
\hline 505.3 & $\operatorname{LPG}(18: 3)^{\mathrm{a}}$ & & 765.5 & PG $(36: 6)$ & $16: 1 / 20: 5$ \\
\hline 507.3 & $\operatorname{LPG}(18: 2)^{\mathrm{a}}$ & & 767.5 & PG $(36: 5)$ & $20: 5 / 16: 0$ and $18: 1 / 18: 4$ \\
\hline 509.3 & LPG $(18: 1)$ & $18: 1$ & 769.5 & PG $(36: 4)$ & $18: 1 / 18: 3$ and $18: 2 / 18: 2$ \\
\hline 691.5 & PG $(30: 1)$ & $14: 0 / 16: 1$ & 771.5 & PG $(36: 3)$ & $18: 1 / 18: 2$ \\
\hline 693.5 & PG (30:0) & $14: 0 / 16: 0$ & 773.5 & PG $(36: 2)$ & $18: 1 / 18: 1$ \\
\hline 711.5 & PG $(32: 5)$ & $16: 1 / 16: 4$ & 571.3 & LPI $(16: 0)$ & $16: 0$ \\
\hline 713.5 & PG (32:4) & $16: 0 / 16: 4$ and $16: 1 / 16: 3$ & 781.5 & PI (30:0) & $14: 0 / 16: 0$ \\
\hline 717.5 & PG (32:2) & $16: 1 / 16: 1$ & 829.5 & PI (34:4) & $16: 0 / 18: 4$ \\
\hline 719.5 & PG $(32: 1)$ & $16: 1 / 16: 0$ and $14: 0 / 18: 1$ & 831.5 & PI (34:3) & $16: 0 / 18: 3$ \\
\hline 739.5 & PG $(34: 5)$ & $16: 1 / 18: 4$ & 833.5 & PI (34:2) & $16: 0 / 18: 2$ \\
\hline 741.5 & PG (34:4) & $16: 1 / 18: 3$ & 835.5 & PI (34:1) & $16: 0 / 18: 1$ \\
\hline 743.5 & PG $(34: 3)$ & $18: 3 / 16: 0$ and $16: 1 / 18: 2$ & 873.5 & PI $(38: 10)^{a}$ & \\
\hline 745.4 & PG $(34: 2)$ & $16: 1 / 18: 1$ and $18: 2 / 16: 0$ & & & \\
\hline
\end{tabular}

907

908

909

910

911

912

913

914

915

916

917

918

919

920

921

922

923

924

Table 6. 


\begin{tabular}{|c|c|c|c|c|c|}
\hline $\begin{array}{l}{[\mathbf{M}+\mathbf{H}]^{+}} \\
m / z\end{array}$ & $\begin{array}{l}\text { Lipid Species } \\
(\mathrm{C}: \mathrm{N})\end{array}$ & Fatty Acyl Chains & $\begin{array}{l}{[\mathbf{M}+\mathbf{H}]^{+}} \\
m / z\end{array}$ & $\begin{array}{l}\text { Lipid Species } \\
(\mathrm{C}: \mathbf{N})\end{array}$ & Fatty Acyl Chains \\
\hline 496.3 & $\operatorname{LPC}(16: 0)^{a}$ & & 806.6 & PC $(38: 6)^{b}$ & \\
\hline 542.3 & $\operatorname{LPC}(20: 5)^{a}$ & & 808.6 & $\operatorname{PC}(38: 5)^{a}$ & \\
\hline 568.3 & $\operatorname{LPC}(22: 6)^{\mathrm{a}}$ & & 828.6 & $\mathrm{PC}(40: 9)^{\mathrm{a}}$ & \\
\hline 706.5 & PC $(30: 0)^{a}$ & & 830.6 & $\mathrm{PC}(40: 8)^{\mathrm{b}}$ & \\
\hline 728.5 & $\mathrm{PC}(32: 3)^{\mathrm{a}}$ & & 452.3 & $\operatorname{LPE}(16: 1)^{\mathrm{a}}$ & \\
\hline 730.5 & $\mathrm{PC}(32: 2)$ & $16: 1 / 16: 1$ & 454.3 & LPE (16:0) & $16: 0$ \\
\hline 754.6 & PC $(34: 4)^{a}$ & & 478.3 & LPE (18:2) & $18: 2$ \\
\hline 756.6 & $\operatorname{PC}(34: 3)^{b}$ & & 480.3 & $\operatorname{LPE}(18: 1)^{\mathrm{a}}$ & \\
\hline 758.6 & $\mathrm{PC}(34: 2)$ & $16: 1 / 18: 1$ & 500.3 & LPE (20:5) & $20: 5$ \\
\hline 760.6 & $\mathrm{PC}(34: 1)$ & $16: 0 / 18: 1$ & 502.3 & LPE (20:4) & $20: 4$ \\
\hline 780.6 & $\operatorname{PC}(36: 5)^{b}$ & & 528.3 & LPE (22:5) & $22: 5$ \\
\hline 784.6 & $\mathrm{PC}(36: 3)$ & $18: 1 / 18: 2$ & 688.5 & $\operatorname{PE}(32: 2)^{c}$ & \\
\hline 786.6 & PC (36:2) & & 690.5 & $\operatorname{PE}(32: 1)^{\mathrm{c}}$ & \\
\hline 804.6 & PC $(38: 7)^{b}$ & & 716.5 & PE (34:2) & $16: 1 / 18: 1$ and $16: 0 / 18: 2$ \\
\hline
\end{tabular}

$927 \quad{ }^{a}$ Molecular species identified only by retention time and mass accuracy calculation.

$928{ }^{b}$ Molecular species of PC identified by retention time, mass accuracy calculation and typical product ion

929 observed at $m / z 184$ in the LC-MS/MS spectrum of $[\mathrm{M}+\mathrm{H}]^{+}$ion.

$930{ }^{\mathrm{c}}$ Molecular species of PE identified by retention time, mass accuracy calculation and typical neutral loss

931 of 141 in the LC-MS/MS spectrum of $[\mathrm{M}+\mathrm{H}]^{+}$ion. 